\title{
Intersectionality in international anti-discrimination law: addressing poverty in its complexity \\ Beth Goldblatt*
}

\begin{abstract}
[* Associate Professor, Faculty of Law, University of Technology, Sydney; Visiting Fellow, Australian Human Rights Centre, Faculty of Law, University of New South Wales; Honorary Senior Research Fellow, School of Law, University of the Witwatersrand. Email: beth.goldblatt@uts.edu.au]
\end{abstract}

\begin{abstract}
The concept of intersectionality has been progressively incorporated into international antidiscrimination law. This article considers the nature of this incorporation and the different understandings of the term and related concepts by United Nations treaty body committees. It discusses the importance of intersectionality within a substantive equality framework in challenging poverty that is often complex in nature. This is illustrated with examples from the field of social security in India, Australia and South Africa as they concern issues of race, gender, caste and class. The article suggests the need for a clear conception of intersectionality embedded within a substantive approach to equality and for greater uniformity of this equality framework across the human rights treaty system.
\end{abstract}

Key words: international anti-discrimination law, substantive equality, intersectionality, social security

\section{Introduction}

The concept of intersectionality has been given express recognition in international law in recent years, although its roots go back some years earlier. Intersectionality has an important role in ensuring that the needs of the most disadvantaged groups are not overlooked in measures to address inequality. This article proposes a clearer integration of the concept of intersectionality within an understanding of substantive equality so as to challenge complex poverty that is enmeshed with inequality. This integrated equality framework requires consistent application across the United Nations (UN) human rights treaty system.

International human rights law contains strong commitments to non-discrimination and equality. As is common in domestic discrimination law, international law refers to discrimination on the basis of certain identified grounds. Listed grounds, for example in Art 2(2) of the International Covenant on Economic, Social and Cultural Rights (ICESCR), include 'race, colour, sex, language, religion, political or other opinion, national or social origin, property, birth or other status'. Entire treaties are dedicated to particular groups facing discrimination and disadvantage, including people defined in terms of their race, women, people with disabilities, children and migrants. The grounds of discrimination are historically contingent categories that are determined by law to represent the varieties of social stigma and harmful distinction that should be prohibited (Thornton 1990, 44-46; Fredman 2011, 110-11). 
In interpreting the injunction against discrimination and the principle of equality, the treaty committees have developed, over some years, a body of commentary on the meaning of equality and non-discrimination and the way in which these concepts should be understood and operationalised by member states. One of the issues that such commentary attempts to address is what happens when discrimination arises in relation to two or more grounds. This question points to the complex nature of inequality that does not always lend itself to redress in terms of distinct legal categories. Thus, the same person might face discrimination related to their race, gender, nationality, class, religion and language. Included within some of the treaty committee responses to this question is the idea of intersectionality. The term, coined by Kimberle Crenshaw (1989), was a response to the 'single-axis framework' of US antidiscrimination law but was also part of a broader critique by black feminists of feminist and antiracist approaches. The idea of intersectionality is that different forms of discrimination arise at the intersection of traditional grounds of discrimination. Thus, black women may encounter different and distinct experiences of discrimination from those experienced by black men or white women and these may not be addressed by considering single forms of discrimination based on race or gender alone. This idea has proved highly influential in feminist legal theory, in feminist theory more broadly and in wider scholarship on identity. It has become an important addition to anti-discrimination law in some jurisdictions and, as noted, has found its way into international law. Its application has gone beyond race and gender to cover the intersection of a range of grounds or categories of discrimination.

Intersectional discrimination should be distinguished from other situations where more than one ground of discrimination is present. Thus, a person may be discriminated against on the basis of a number of grounds rather than on the basis of a new form of discrimination that arises at the intersection of two grounds. This compounded or additive discrimination means that more than one type of discrimination is directed at a single person. For example, a club may prohibit admission by women, black people and Jews. A black Jewish woman would be discriminated against on the basis of three grounds and could assert her claim of discrimination on the basis of any or all of these. This is different from the situation where a single provision may discriminate against more than one group on the basis of different grounds (Albertyn and Goldblatt 2007, 52). For example, a law might prevent unmarried couples from accessing certain benefits that married couples are entitled to. This could discriminate against same-sex couples unable to marry (discrimination on the basis of sexual orientation) and couples married in terms of Muslim law whose marriages may not receive official recognition (discrimination on the basis of religion). Both of these should be distinguished from intersectional discrimination where, for example, able-bodied women or men with disabilities might not experience the particular forms of discrimination that women with disabilities face, such as forced sterilisation and heightened exposure to sexual abuse.

Conaghan (2009) raises important critiques about the limits of intersectionality in producing theory that explains inequality and the broader relations that produce it. She argues that intersectionality is overly 'bound up with notions of identity and identity formation' that, while important, are insufficient in investigating structural economic and distributive causes of disadvantage and their relationship to issues of identity/recognition $(2009,29-30)$. Her conclusion is that 'law's equality-seeking strategies should flow directly from an analysis of the (inter)operation of inequality regimes, including but not restricted to the ordering effects of law itself' $(2009,42)$. This challenging approach requires an awareness of the limits of intersectionality as a concept, but also points to the need to ensure that use of this concept is thoroughly integrated within a deep understanding of inequality and its multiple causes and a sophisticated and far-reaching vision of equality. 
In taking on this challenge, this article argues that the concept of intersectionality should be embedded within a multidimensional understanding of substantive equality. Substantive equality is a concept developed in response to a formal notion of equality that requires everyone to be treated alike. This formal equality approach would limit affirmative measures aimed at overcoming the historic disadvantages of certain groups. It is likely to perpetuate disadvantage if it does nothing more than open up opportunities on an equal basis. For example, removing legal barriers to the employment of people with disabilities will not necessarily lead to their equal representation in the labour force. A substantive equality approach recognises that more active efforts are needed to address underlying, systemic inequalities if real change is to result. A multidimensional understanding of substantive equality requires status-related and distributive inequalities to be addressed alongside inequalities in participation, as well as measures to be taken to accommodate difference and transform institutions (Fredman 2011). This article suggests that a close connection between this understanding of equality and social and economic rights will assist in responding to complex poverty. Poverty, like inequality, is multidimensional. Complex poverty arises where a range of social, cultural and economic factors converge to deepen and entrench material disadvantage (Bradshaw 2007). For example, a child may be denied education because of her gender, leading to poor employment outcomes and consequent inability to obtain adequate food or healthcare. Another illustration of the complexity of poverty is where a girl's inadequate nutrition (sometimes arising because sons are given preference where food is scarce) may lead to poor health that affects her ability to generate a sustainable livelihood. Disempowerment, discrimination and stigma are some of the factors that complicate, deepen and entrench poverty.

The article begins by examining the way in which the concept of intersectionality has developed within international law. It shows that there is a growing acceptance of the need to examine inequality intersectionally, but that this is not always fully integrated into a substantive equality approach and is not articulated consistently across the UN human rights system. The article then looks at three examples in the field of social security and social protection to illustrate the need for a fuller intersectional equality framework within international law that can aid in addressing poverty in its complexity. The first example concerns India's Mahatma Gandhi National Rural Employment Guarantee Act; the second example considers the policy of income management within Indigenous communities in Australia's Northern Territory; and the third example discusses the extension of South Africa's aged pension to a group of men previously excluded from this benefit. These examples illustrate the need to tease out the layers of discrimination that shape poverty and disadvantage and the importance of an effective equality framework to aid in this process. In the final section, the article discusses why a clearer reframing of intersectionality within international anti-discrimination law would be of benefit at the international and domestic level, the features of such a framework, and the need for a more consistent or unified articulation of intersectionality within substantive equality across the treaty system.

\section{Intersectionality in international law}

The close connection between poverty and inequality requires human rights responses that are able to engage with the complex forces that shape social and economic disadvantage. This section of the article surveys the development of the idea of intersectionality within international anti-discrimination law as one of the responses to this challenge. It finds that there is a growing understanding of this concept, but that this is not consistent across the treaty bodies and should be more closely integrated within a substantive equality framework. 
International human rights law contains a range of references that challenge unitary notions of discrimination within single categories. ${ }^{1}$ The Convention on the Elimination of All Forms of Discrimination against Women (CEDAW), adopted in 1979, refers in its preamble to issues of race and poverty affecting women. There are Articles on rural women (Art 14), nationality (Art 9), girls (Art 10) and marital status (Arts 16 and 1) that highlight the connections between arenas of discrimination. The Convention on the Rights of the Child (CRC), adopted in 1989, contains articles on children with disabilities (Art 23) and refugee children (Art 22). The newer Convention on the Rights of Persons with Disabilities (CRPD), adopted in 2006, specifically mentions women with disabilities where it says: 'States Parties recognize that women and girls with disabilities are subject to multiple discrimination, and in this regard shall take measures to ensure the full and equal enjoyment by them of all human rights and fundamental freedoms' (Art 6(1)).

Over the past 15 years, the treaty bodies responsible for the various human rights instruments have identified a range of terms to discuss discrimination implicating more than one ground. These are now surveyed to demonstrate the evolving understanding of intersectionality within international law. ${ }^{2}$

In 2000, the Committee on the Elimination of Racial Discrimination produced General Recommendation No 25 on the gender-related dimensions of racial discrimination. The Committee made the following commitment: 'Recognizing that some forms of racial discrimination have a unique and specific impact on women, the Committee will endeavour in its work to take into account gender factors or issues which may be interlinked with racial discrimination' (para 3, emphasis added). It gave examples of 'racial bias-motivated rape', abuse of domestic workers and forced sterilisation of indigenous women (para 2). The Committee called for improved qualitative and quantitative reporting by states with disaggregated data on race and gender. While the word 'interlinked' was used, the examples illustrate an intersectional understanding of race and gender discrimination.

Also in 2000, the Human Rights Committee, responsible for the International Covenant on Civil and Political Rights, in General Comment No 28 on Art 3 (the equality of rights between men and women) noted that:

\begin{abstract}
Discrimination against women is often intertwined with discrimination on other grounds such as race, colour, language, religion, political or other opinion, national or social origin, property, birth or other status. States parties should address the ways in which any instances of discrimination on other grounds affect women in a particular way, and include information on the measures taken to counter these effects. [Paragraph 30, emphasis added.]
\end{abstract}

The Committee also referred to the position of women in minority communities (para 32). Here, the word 'intertwined' was used in relation to discrimination of women on a range of grounds. The notion that certain women might experience discrimination in a 'particular way' seems to reflect an appreciation of intersectional discrimination.

\footnotetext{
${ }^{1}$ For earlier discussions of intersectionality in international law, see Crooms 1997; Green 2002; Makkonen 2002; and Bond 2003. For a discussion of intersectionality in European Union law, see Bullock and Masselot 2012. For a discussion of intersectionality and Australian anti-discrimination law, see Mansour 2012.

${ }^{2}$ This involved a survey of human rights treaties and the General Comments and Recommendations of the relevant treaty bodies. It also considered treaty body reporting guidelines. It did not examine treaty body jurisprudence, Concluding Observations and Recommendations or the work of special mandates holders. A larger mapping of intersectionality within international anti-discrimination law would be a valuable project.
} 
Thus far, references to intersectionality, albeit using different language, referred specifically to women. In 2009, the Committee on Economic Social and Cultural Rights (CESCR) in General Comment No 20 on non-discrimination in economic, social and cultural rights (Art 2, para 2, of the ICESCR) provided a more general consideration of the grounds of discrimination within a discussion of substantive equality. It stressed the need to ensure substantive and not just formal equality. In so doing, it provided some guidance on the determination of grounds of discrimination when it stated that:

\begin{abstract}
Eliminating discrimination in practice requires paying sufficient attention to groups of individuals which suffer historical or persistent prejudice instead of merely comparing the formal treatment of individuals in similar situations. States parties must therefore immediately adopt the necessary measures to prevent, diminish and eliminate the conditions and attitudes which cause or perpetuate substantive or de facto discrimination. For example, ensuring that all individuals have equal access to adequate housing, water and sanitation will help to overcome discrimination against women and girl children and persons living in informal settlements and rural areas. [Paragraph 8(b).]
\end{abstract}

It noted that the grounds of discrimination listed within the ICESCR (Art 2(2)) are not based on a closed list (paras 15 and 27). Notably, in listing new grounds not mentioned in the Covenant - such as disability, nationality and sexual orientation - the General Comment also referred to the ground of economic and social situation (or class) (para 35). This is an important recognition of the links between poverty and substantive inequality specific to a range of groups.

The CESCR also noted that discrimination may occur on multiple grounds (para 17). It stated that:
Some individuals or groups of individuals face discrimination on more than one of the prohibited grounds, for example women belonging to an ethnic or religious minority. Such cumulative discrimination has a unique and specific impact on individuals and merits particular consideration and remedying. [Paragraph 17, emphasis added.]

Although the term 'cumulative discrimination' is used, the definition is aligned with the meaning of intersectional discrimination. A little later in the General Comment, there is mention of the possibility of new forms of discrimination at 'the intersection of two prohibited grounds of discrimination, e.g. where access to a social service is denied on the basis of sex and disability' (para 27, emphasis added). Following this reference in the General Comment, the terms 'intersection' and 'intersectionality' started to appear more frequently in treaty body commentary.

Although the examples used in CESCR General Comment No 20 to illustrate intersectionality are of women, the implication of the overall equality framework is that intersectional discrimination can be directed at a wide range of groups, including men facing various forms of discrimination. ${ }^{3}$ The Committee on the Rights of the Child also pointed to intersectional discrimination that was not based on gender. In General Comment No 11 (2009, on indigenous children and their rights under the Convention), the Committee required special measures that:

\footnotetext{
${ }^{3}$ Some of the treaty committee reporting guidelines are also gender neutral. See United Nations Secretary General 2009 for the combined guidelines which refer to 'multiple discrimination' (14, paras 51 and 55), while the Committee on the Elimination of Racial Discrimination reporting guidelines( 60, para IIB) refer to 'complex forms of disadvantage'. [UN Sec General 2009]
} 
... consider the needs of indigenous children who may face multiple facets of discrimination and also take into account the different situation of indigenous children in rural and urban situations. Particular attention should be given to girls in order to ensure that they enjoy their rights on an equal basis as boys. States parties should furthermore ensure that special measures address the rights of indigenous children with disabilities. [Paragraph 29, emphasis added, footnote omitted.]

The Committee on the Rights of the Child also produced General Comments on various forms of discrimination that intersect with discrimination experienced by children, including on the basis of disability (No 9) and HIV/AIDS (No 3) and noted the existence of 'multiple forms of discrimination' in relation to the health rights of children (No 15). The Committee's expansion of the notion of intersectionality to new groups was an important progression of the concept within international law.

Returning to a focus on women facing intersectional discrimination, The Committee on the Elimination of Discrimination against Women (CEDAW Committee) produced General Recommendations on a range of specific groups of women, including older women (2010), women with disabilities (1991) and migrant women (2008). Its 2004, General

Recommendation No 25 on temporary special measures was an effort by the Committee to bring a range of different terms and approaches within the UN human rights system into alignment (para 13) under the banner of a clearly articulated notion of substantive equality (paras 8-19) in pursuit of the goal of transformation (para 10). It defined substantive equality as requiring that:
... women be given an equal start and that they be empowered by an enabling environment to achieve equality of results. It is not enough to guarantee women treatment that is identical to that of men. Rather, biological as well as socially and culturally constructed differences between women and men must be taken into account. Under certain circumstances, non-identical treatment of women and men will be required in order to address such differences. Pursuit of the goal of substantive equality also calls for an effective strategy aimed at overcoming underrepresentation of women and a redistribution of resources and power between men and women.

This approach to substantive equality called for a contextual and historical understanding of the multiple forms of systemic gender inequality (paras 10-11). The discussion of discrimination against women on the basis of more than one ground was located within this approach. The CEDAW Committee noted that:

Certain groups of women, in addition to suffering from discrimination directed against them as women, may also suffer from multiple forms of discrimination based on additional grounds such as race, ethnic or religious identity, disability, age, class, caste or other factors. Such discrimination may affect these groups of women primarily, or to a different degree or in different ways than men. States parties may need to take specific temporary special measures to eliminate such multiple forms of discrimination against women and its compounded negative impact on them. [Paragraph 12, emphasis added.]

This consideration of grounds of discrimination against women, although not phrased as intersectionality, was the first discussion by a treaty committee to link the concept of intersectionality to the idea of positive measures within a broader endorsement of the goal of substantive equality.

This was restated in 2010 by the CEDAW Committee in General Recommendation No 28 on the Core Obligations of States Parties under Art 2 of CEDAW, this time with specific mention of the term 'intersectionality'. The statement also required a general prohibition against intersectional discrimination and the need for policies and programs to ensure this, including temporary special measures. The General Recommendation included a broad commitment to the principle of substantive equality (para 24). It noted that: 
Intersectionality is a basic concept for understanding the scope of the general obligations of States parties contained in article 2 . The discrimination of women based on sex and gender is inextricably linked with other factors that affect women, such as race, ethnicity, religion or belief, health, status, age, class, caste and sexual orientation and gender identity. Discrimination on the basis of sex or gender may affect women belonging to such groups to a different degree or in different ways to men. States parties must legally recognize such intersecting forms of discrimination and their compounded negative impact on the women concerned and prohibits them. They also need to adopt and pursue policies and programmes designed to eliminate such occurrences, including, where appropriate, temporary special measures in accordance with article 4, paragraph 1, of the Convention and general recommendation No. 25.

[Paragraph 18, emphasis added.]

The CEDAW Committee has provided a valuable definition of the term 'intersectionality' that is linked to remedial measures to achieve substantive equality. However, the more transformative understanding of substantive equality contained in the Committee's 2004 General Recommendation is not explicit in this definition.

Other committees have highlighted discrimination against women on the basis of more than one ground. The Committee for the Rights of Persons with Disabilities in its first General Comment on Equal Recognition before the Law (2014) noted that the CRPD 'recognizes that women with disabilities may be subject to multiple and intersectional forms of discrimination based on gender and disability'. It gave the examples of women with disabilities 'subjected to forced sterilization', and 'denied control of their reproductive health and decision-making' on the assumption that 'they are not capable of consenting to sex' (para 35, emphasis added). The Committee for Migrant Workers has also noted the links between discrimination on the basis of migrant status and gender in relation to domestic workers (General Comment No 1, para 7). This is a crucial acknowledgment of the links between poverty, vulnerability and traditional grounds of discrimination that are generating new forms of discrimination in a changing global context.

In its recent (2014) joint General Recommendation/Comment (No 31) on harmful practices, the CEDAW Committee, together with the Committee on the Rights of the Child, stated that:

Harmful practices are persistent practices and behaviours that are grounded on discrimination on the basis of sex, gender, age and other grounds as well as multiple and/or intersecting forms of discrimination that often involve violence and cause physical and/or psychological harm or suffering. [Paragraph 14, emphasis added.]

It also noted that:

... sex- and gender-based discrimination intersect with other factors that affect women and girls, in particular those who belong to, or are perceived as belonging to disadvantaged groups, and who are therefore at a higher risk of becoming victims of harmful practices. Harmful practices are therefore grounded in discrimination based on sex, gender, age and other grounds and have often been justified by invoking socio-cultural and religious customs and values as well as misconceptions related to some disadvantaged groups of women and children. [Paras 5-6, emphasis added, footnote omitted.]

Examples include 'female genital mutilation, child and/or forced marriage, polygamy, crimes committed in the name of so-called honour and dowry-related violence' (para 6). The Committees also stated that:

Many other practices have been identified as harmful practices which are all strongly connected to and reinforce socially constructed gender roles and systems of patriarchal power relations and sometimes reflect negative perceptions or discriminatory beliefs towards certain disadvantaged groups of women and children, including individuals with disabilities and albinism. [Paragraph 8, emphasis added.] 
The joint General Recommendation/Comment contains a sophisticated discussion of the multidimensional structural underpinnings of harmful practices leading to violations of the civil, political, economic, social and cultural rights of women and girls and provides a rich suite of recommendations.

In another recent General Recommendation (2014), No 32 on the gender-related dimensions of refugee status, asylum, nationality and statelessness of women, the CEDAW Committee drew from the earlier General Recommendation No 28 when it reaffirmed that:

\footnotetext{
Discrimination against women based on sex and/or gender is often inextricably linked with and compounded by other factors that affect women, such as race, ethnicity, religion or belief, health, age, class, caste, as well as being lesbian, bisexual or transgender (LBT) and other status. Discrimination on the basis of sex or gender may affect women belonging to such groups to a different degree or in different ways to men. States parties must legally recognize such intersecting forms of discrimination and their compounded negative impact on the women concerned and prohibit them. [Paragraph 6, emphasis added, footnote omitted.]
}

The General Recommendation is strongly intersectional in approach in requiring a genderbased understanding of international refugee law and a contextual understanding of the specific factors that result in women seeking asylum (para 16).

The CEDAW Committee through its General Recommendations has demonstrated an increasingly developed understanding of and approach to intersectionality.

This discussion of the treaty body statements on intersectionality illustrates the evolution of the concept over the past 15 years. A range of terms has been used, such as 'intertwined', 'cumulative', 'compounded' and 'multiple' discrimination, as well as more recent references to 'intersecting' discrimination and 'intersectionality'. Some of these references (particularly those of the CEDAW Committee and the CESCR) are closely related to a broader articulation of substantive equality, while others have simply pointed to the need for states parties to be aware of the complex nature of discrimination. The CEDAW Committee definition of intersectionality in 2010, while important, would be improved by linking its concept of positive measures to address discrimination to the same Committee's more transformative approach to substantive equality of 2004. The valuable linking of intersectional discrimination to economic inequality and poverty, highlighted by the CESCR in 2009, should also inform the way intersectionality is understood within international law.

Before moving to a consideration of how the concept of intersectionality could be more clearly and consistently articulated within a full understanding of substantive equality that can address complex poverty, this article now provides some country-based examples that demonstrate the need for such a framework.

\section{Intersectional considerations: examples from social security and social protection}

International law can offer a rich framework for understanding discrimination intersectionally within efforts to address poverty linked to disadvantage. To illustrate the need for a fuller conception of intersectionality within international and domestic law, the following examples are drawn from the field of social security and social protection in India, Australia and South Africa. They concern social assistance measures to address poverty in South Africa and Australia and a public works program in India.

\section{India's rural public works scheme}


The first example concerns the Mahatma Gandhi National Rural Employment Guarantee Act, 2005 (known as NREGA). This is a highly celebrated public works program introduced in 2006. The Act entitles every rural household whose adult members volunteer to undertake unskilled manual work at least 100 days per year at the statutory minimum wage. If an applicant is not provided with work within 15 days, he or she must be provided with an unemployment allowance. In the financial year of 2013-14, NREGA reached almost 50 million households (Ministry of Rural Development, India 2014). It is hailed as the largest public works program in the world and is proving significant in mitigating the impacts of poverty in rural India. It has, however, had various implementation problems and there are some critiques of its design.

Of significance for present purposes, the Act contains affirmative action measures. Thus, one-third of workdays are reserved for women (Sch II, s 6). The Act also builds in one-third representation of both women and members of 'Scheduled Castes, Scheduled Tribes, the Other Backward Classes and Minorities' as non-official members of the central (s 10(3)(d)) and state (12(1)) government bodies responsible for the scheme. Public works on land owned by Scheduled Castes and Tribes is given some priority (Sch I, s 1(iv)). ${ }^{4}$

The promotion of vulnerable groups, particularly women, through NREGA is a significant feature of the scheme. It empowers rural women by giving them access to employment outside of the home and their own income, often for the first time. Similarly, for women who are not provided with work but who are paid through the unemployment allowance, this may be a rare opportunity to access income in their own right. In addition, women are paid at the same rate as men, unusual for many women in India (Khera and Nayak 2011, 81). Women are paid into their own bank or post office accounts (which is mandatory unless there is an official exemption of this requirement), also a beneficial new experience for many rural women. Since payment is at a higher rate than in the private sector, this may push up women's wages in the agricultural sector as a whole and reduce the gender wage gap (Dasgupta and Sudarshan 2011, 14-15).

The guidelines for the implementation of the Act (Ministry of Rural Development, India $2013,9.6)$ recognise the vulnerability and particular needs of 'women in special circumstances' (widowed women, deserted women and destitute women). This is critically important in the Indian context, where single women often face discrimination and stigma. The guidelines recommend that the administering body identify such women and ensure that they are provided with 100 days of work (9.6). They also make special provision for pregnant and lactating mothers ( 8 months before delivery and 10 months after), recommending work requiring less effort and that is closer to their homes (9.6.1). The needs of other vulnerable groups - including the elderly, people with disabilities, people who are internally displaced, nomadic tribes and particularly vulnerable tribal groups - are also addressed in the guidelines (9.2-9.9). There are detailed suggestions about ways of including these groups and specific forms of work that people with disabilities and older persons could be provided with. In this way, NREGA promises, at least on paper, to be deeply mindful of different forms of discrimination and intersectional discrimination.

However, the extent to which such directives are being followed on the ground is difficult to assess if one looks at the statistical data provided by the government. The 2013-14 NREGA

\footnotetext{
${ }^{4}$ See the recommendations by Holmes, Sadana and Rath (2010) for community assets to reduce gender-specific vulnerabilities, especially for women, in Scheduled Castes and Scheduled Tribes.
} 
figures show that women made up 52 per cent of person days on the program. The figures also indicate that Scheduled Castes made up 22 per cent of these person days and Scheduled Tribes made up 17 per cent and just 0.65 per cent for people with disabilities (Ministry of Rural Development, India 2014). The figures do not, however, provide a breakdown of gender within the groups of Scheduled Castes and Tribes. This means that men might be dominating access to work in these households and the figures will not illustrate this possibly skewing.

Thus, although women are well represented within NREGA, it is also important to ensure that they are adequately represented within other prioritised groups so that the most vulnerable groups, containing people at the intersection of gender and caste discrimination, do not lose out. Improved data collection might point to the need for measures to ensure the participation of such groups. A substantive equality framework that incorporates intersectionality for treaty bodies would ensure that countries such as India are encouraged to build in more extensive disaggregated data collection so as to assess whether significant programs such as NREGA are achieving their equality goals and, if they are not, to take measures to address this. In this way, the complexities of poverty and discrimination would be examined and understood more clearly and addressed more fully through law and policy changes.

\section{Income management of welfare in Australia}

The second example stands in contrast to NREGA, as it concerns an attempt to control access to social security. Introduced in 2007 as an 'intervention' Indigenous women and children in Australia's Northern Territory, the Northern Territory Emergency Response Act 2007 (Cth) (NTER) contained a suite of racially discriminatory measures. In order to pass the legislation introducing the NTER into Indigenous communities, the government suspended the operation of the Racial Discrimination Act 1975 (Cth). The suspension was later lifted when the NTER was extended to all inhabitants of the Northern Territory. One feature of the package involves the compulsory management of people's social security income by quarantining 50 per cent of it and placing this on what is called a 'Basics Card'. The card can only be used at certain stores to purchase certain products. The stated aim of the measure was to prevent Indigenous welfare recipients from purchasing alcohol and cigarettes and gambling with the money. It was also designed ostensibly to prevent what is known as 'humbugging', where welfare recipients are bullied or 'guilt-tripped' into handing over a portion of their welfare income. ${ }^{6}$

The major outcry over the NTER and income management has concerned race discrimination. This has occurred both domestically and through complaints to and reports by international treaty bodies. The UN's Special Rapporteur on the Rights of Indigenous Peoples, James Anaya, questioned the characterisation of the NTER as a special measure, given its racially discriminatory features (Anaya 2010, paras 19-29). He noted that:

This regime applies to all those living in prescribed areas inhabited by indigenous peoples, regardless of whether or not they have responsibilities over children or have been shown to have problems managing income in the past. By contrast, outside of the prescribed areas, income quarantining applies only on a

\footnotetext{
${ }^{5}$ It was later renamed 'Stronger Futures' under a subsequent government and described as a 'special measure'.

${ }^{6}$ For a discussion of the problematic features of income management on Indigenous communities, see Cox 2011 and Bielefeld 2014.
} 
case-by-case basis in demonstrated situations of neglect, abuse, or inadequate school attendance. [3A para 13.]

In addition, the Human Rights Committee (2009) and the Committee on the Elimination of Racial Discrimination (2010) called on the Australian government to ensure that the NTER was redesigned to comply with the requirements of appropriate and non-discriminatory special measures involving the participation of Indigenous people in this process. The focus of these groups was on race rather than gender discrimination because of the suspension of the Racial Discrimination Act and the targeting of Indigenous communities.

What has not been noted by many commentators is that women (at 61 per cent) are the numerically dominant subjects of income management (Bray et al 2012, 57-58). While the measures were supposedly designed to help women and children, they have resulted in deepening the intersectional discrimination experienced by Indigenous women (Goldblatt 2014). One study of women's experiences of income management found the Basics Card demeaning and stigmatising and that it limited consumer choices, creating more inconvenience and less opportunity for careful spending (Equality Rights Alliance 2011). Another study, by the Australian Law Reform Commission, found that compulsory income management could be dangerous and inappropriate in the context of family violence, since it removes control and further disempowers people who are exposed to such violence (2011, 247-83). Watson has argued that income management resonates with the experiences of Indigenous women historically who were subject to the control of white protectors to whom they had to surrender their wages and welfare payments (2011).

The focus on race discrimination in relation to criticism of compulsory income management within the NTER has been inadequately intersectional both in the examination of the impact of the measures and in the responses to the measures. A more integrated approach to intersectionality within international treaty body consideration of this issue would have pointed to the additional and particular inequalities experienced by Indigenous women. The example also illustrates the need to unpack supposedly beneficial special measures to consider whether they enhance the equality rights of the range of groups affected by the measures. An improved international law equality framework would offer a more systematic critique of Australia's income management measures and would point to the need for more participatory, sophisticated and transformative responses to the complex poverty and inequality experienced by Indigenous Australians in all their diversity. ${ }^{7}$

\section{Equalising the pension in South Africa}

The final example concerns a challenge to a social security benefit that advantaged men over women. The government-provided pension, previously called the Old Age Pension and now known as the Older Persons Grant, is a means-tested social assistance benefit that is effective in addressing poverty in South Africa. From the 1930s, the pension was provided to women at the age of 60 and to men at the age of 65. In 2007, a group of men went to court to raise a constitutional challenge against the legislation authorising this age difference on the basis of

\footnotetext{
${ }^{7}$ While the rights of indigenous peoples are recognised by the UN (United Nations Declaration on the Rights of Indigenous Peoples) and various UN concerns with the NTER have been noted, the Australian government has failed to address such concerns. The limitations of the human rights treaty system in this regard has led Watson (2012) to call for an international mechanism to manage disputes between indigenous peoples and nonindigenous peoples/colonial powers.
} 
their rights to social security and equality (Roberts $v$ Minister of Social Development, 2007). The government, in opposing this challenge, argued that the differential ages of eligibility were a positive measure to advantage women, who were a particularly disadvantaged group in society (Goldblatt and Rosa 2014, 262). The government's arguments were premised on a contextual, historical and intersectional analysis of the position of black women under apartheid which, they argued, had created a legacy of disadvantage for this group of older women.

This intersectional analysis, while accurate, pitted poor, elderly, black women against poor, elderly, black men in a contest over who was most disadvantaged. What is interesting about this approach was the assumption that substantive equality required choosing the worst off. However, a substantive equality approach, combined in this case with a commitment to social and economic rights (here, the right to social security) should not encourage a 'race to the bottom' for the most intersectionally vulnerable. Instead, it should ensure that distributive equality is achieved without losing sight of the needs of various disadvantaged groups. While the oppositional nature of litigation and a mechanical response to anti-discrimination and rights-based challenges can lead to narrow arguments such as this one, they should not prevent courts or other adjudicatory bodies from finding more nuanced and creative responses. For example, a court could have required equalisation of the pension while also encouraging further measures to address the particular circumstances of elderly women, such as better access to appropriate services. ${ }^{8}$ A clear framework at the international law level that encourages such a response could inform domestic responses to complex challenges that implicate poverty and intersectional disadvantage.

\section{Improved intersectional equality frameworks}

Before discussing how a consistent and fuller articulation of intersectionality might benefit the work of the treaty bodies and UN human rights agencies to address complex poverty and inequality, this section of the article will consider why such a framework is important for domestic efforts to achieve equality.

Clear intersectional frameworks in international anti-discrimination law are important for the domestic implementation of human rights for a number of reasons. First, international law, through its reporting system, is used to monitor the practices of states parties to assess whether these are compliant with human rights. Anti-discrimination frameworks enable systemic evaluations of a country's progress in addressing the circumstances of vulnerable and disadvantaged groups. Thus, for example, a fuller focus on intersectional disadvantage might have led the UN Committees to highlight the gender discrimination involved in Australia's NTER.

Second, the system of reporting requires states parties to account for their deficiencies and report on their progress in realising human rights. This requires states parties to collect data on many aspects that may not have been captured previously, including detailed demographic breakdowns and disaggregation based on new categories of social vulnerability. This data collection may become instructive within states parties and at the international level in pointing to problem areas that require redress and improvement. For example, requesting

\footnotetext{
${ }^{8}$ In a strange turn of events, the South African government did not wait for the court's judgment but proceeded to alter the legislation, resulting in a staged equalisation of the pension (Goldblatt and Rosa 2014, 261-64).
} 
India to provide a more detailed demographic breakdown of NREGA workers might point to areas for improvement in the scheme.

Third, international anti-discrimination law both is influenced by domestic antidiscrimination law and in turn influences its development at the national level. Thus, appropriate frameworks at the international level have the potential to inform and shape the understandings of states parties and courts with regard to intersectional equality. The government's response to the court challenge to the pension in South Africa might have benefitted from consideration of a clear international law framework, while international law responses to intersectional inequality might gain from a consideration of this issue in domestic jurisprudence and legislation. It is important to acknowledge, however, that states parties sometimes ignore UN Committees and international human rights law as a whole. The progressive development of domestic and international law is clearly limited where this occurs.

Finally, international anti-discrimination law is, like the law in many countries, divided into categories housed in separate treaties on women, race, disability and age (children). This approach, as with the emphasis on grounds within anti-discrimination law, can be valuable in providing focused attention on the specificities of discrimination in different social arenas. However, too much rigidity as a result of these separate locations can be harmful if this closes the space for intersectional complaints. A clear international equality law framework that integrates intersectionality can provide guidance for the development of improved domestic anti-discrimination laws and policies.

At the treaty body and broader UN level, a clearer articulation of intersectionality within an understanding of substantive equality can encourage a focus on the complexities of discrimination and the need for far-reaching and sophisticated responses. Understanding how such discrimination contributes to poverty as a complex phenomenon can also focus attention on the important links between equality and social and economic rights (Liebenberg and Goldblatt 2007). ${ }^{9}$ There is growing awareness within the international human rights system of new grounds of discrimination that were not listed in the founding human rights documents. Thus, LGBTI people, older persons and indigenous peoples are just some of the groups gaining increasing recognition. The idea that grounds of discrimination can expand and change introduces the space for a more flexible approach to grounds. It opens the space for a fuller awareness of intersectionality. This more expansive approach to grounds requires increased attention to context and evidence of the complexities of human experience. It also focuses attention on the need to unravel the layers of vulnerability and disadvantage in inquiring into discrimination. This contextual approach values the importance of grounds as markers of inequality, but is not fixated on their mechanical application. It combines attention to grounds within a contextual enquiry that is central to a substantive equality approach. As noted by the CEDAW Committee (in General Recommendation No 25, 2004) substantive equality requires social transformation based on an understanding of the historical and systemic forces that shape inequality. Within this contextual inquiry, the injunction to look at the intersections of discrimination leads to a fuller appreciation of group-based disadvantage and harm and helps to shape more nuanced and effective responses. This enquiry should also

\footnotetext{
${ }^{9}$ It is important to note that it is not only social and economic rights that can be used positively to ensure distribution of resources and other measures to address material hardship (see Fredman 2008b). For a discussion of non-discrimination in international labour law and its role in addressing poverty and 'class-based socioeconomic inequality', see Sheppard 2012.
} 
pay attention to the multidimensional nature of inequality, which concerns status-based subordination, distributive disadvantage, failure to accommodate difference and lack of participation (Fredman 2008a). While a focus on intersectional discrimination separate from a substantive equality framework can lead to either overwhelming attention to ever-more detailed forms of disadvantage or unhelpful hierarchies of vulnerability, an integrated understanding of intersectionality embedded within a substantive equality approach can generate creative, practical and structural responses that lead to transformative outcomes.

As discussed in the review of treaty body General Comments and recommendations, there is not a consistent approach to the issue of intersectionality across the work of the committees. Some committees have provided quite limited guidance on the issue of equality and intersectionality. A single General Comment on equality that relates to all committees or specific General Comments for those committees that have not addressed this issue adequately would be valuable. The Harmonized Guidelines for states parties' reports set out what is required regarding non-discrimination and equality (United Nations Secretary General 2009, paras 50-59), but this document does not use the term 'substantive equality' or give content to this concept. It also does not use the term 'intersectionality', instead using the term 'multiple discrimination' - which suggests an additive approach rather than one that acknowledges new forms of discrimination that arise at the intersection of two or more grounds. The requirement that states parties provide demographic and other statistical data is not linked to the need for analysis of inequality within each state. ${ }^{10}$ It is suggested that these guidelines be improved so as to build in a more substantive understanding of equality and a fuller consideration of intersectionality to inform state reporting. ${ }^{11}$ This approach could also be followed by states within the Universal Periodic Review process.

\section{Conclusion}

This article has considered how intersectionality is understood within international antidiscrimination law. It has found a growing awareness of this issue, but an inconsistent elaboration of the concept within the treaty system. Second, it has looked at social protection measures in three countries to illustrate the need for clearer frameworks that locate intersectionality within a substantive approach to equality. Lastly, it has pointed to the value of improved international law frameworks, what these should contain and how they might be more consistently applied across the treaty system. This might contribute to addressing poverty, which is complex in nature and intimately linked to discrimination and disadvantage. While law's regulatory function and its categorising role serve to reinforce the status quo (Grabham 2009, 192), law can also be subverted and reimagined to pose questions about the nature and causes of poverty and inequality and to propose new ways of tackling these. Antidiscrimination law that brings to light systemic (intersectional) inequality and responds robustly and creatively to this challenge has the potential to be transformative.

\footnotetext{
${ }^{10}$ Although the list of indicators in Appendix 3 contains the intersectional category of 'single parent and female headed households' and the requirement that socio-economic indicators be disaggregated by sex, age and main population group.

${ }^{11}$ See the recent Resolution adopted by the UN General Assembly on strengthening and enhancing the effective functioning of the human rights treaty body system (2014). For earlier suggestions of treaty system reform to address intersectionality, see Bond 2003.
} 


\section{References}

\section{South African case}

Roberts $v$ Minister of Social Development (unreported decision of the Transvaal Provincial Division, Case Number 32838/05)

\section{Australian legislation}

Northern Territory Emergency Response Act 2007 (Cth)

Racial Discrimination Act 1975 (Cth)

\section{Indian legislation}

Mahatma Gandhi National Rural Employment Guarantee Act, 2005

\section{International legal materials}

Convention on the Elimination of All Forms of Discrimination against Women, adopted 18 December 1979, entered into force 3 September 1981, 1249 UNTS 13

Convention on the Rights of Persons with Disabilities, adopted 13 December 2006, entered into force 3 May 2008, UN Doc A/61/106

Convention on the Rights of the Child, adopted 20 November 1989, entered into force 2 September 1990, 1577 UNTS 3

International Convention on the Elimination of All Forms of Racial Discrimination, adopted 21 December 1965, entered into force 4 January 1969, 660 UNTS 195

International Convention on the Protection of the Rights of All Migrant Workers and Members of Their Families, adopted 18 December 1990, entered into force 1 July 2003, 2220 UNTS 3

International Covenant on Civil and Political Rights, adopted 16 December 1966, entered into force 3 January 1976, 999 UNTS 171

International Covenant on Economic, Social and Cultural Rights, adopted 16 December 1966, entered into force 23 March 1976, 993 UNTS 3

United Nations General Assembly United Nations Declaration on the Rights of Indigenous Peoples, 13 September 2007, A/RES/61/295

United Nations General Assembly Resolution on Strengthening and enhancing the effective functioning of the human rights treaty body system, 9 April 2014, A/RES/68/268

\section{Other references}

Albertyn C and Goldblatt B (2007) 'Equality' in S Woolman et al (eds) Constitutional Law of South Africa Juta, Cape Town pp 1-82 
Anaya J (Special Rapporteur on the Situation of Human Rights and Fundamental Freedoms of Indigenous People) (2010) Situation of Indigenous People in Australia 4 March, A/HRC/15/37/Add.4

Australian Law Reform Commission (2011) Family Violence and Commonwealth Laws Improving Legal Frameworks: Final Report

Bielefeld S (2014) 'Compulsory income management and indigenous peoples: exploring counter narratives amidst colonial constructions of "vulnerability" 36 Sydney Law Review 695

Bond J (2003) 'International intersectionality: a theoretical and pragmatic exploration of women's international human rights violations' 52 Emory Law Journal 71-186

Bradshaw T K (2007) 'Theories of poverty and anti-poverty programs in community development' 38 Community Development 7-25

Bray J, Gray M, Hand K, Bradbury B, Eastman C and Katz I (2012) Evaluating New Income Management in the Northern Territory: First Evaluation Report Social Policy Research Centre, Sydney

Bullock J and Masselot A (2012) 'Multiple discrimination and intersectional disadvantages: challenges and opportunities in the European Union legal framework' 19 Columbia Journal of European Law 57-82

Committee on Economic, Social and Cultural Rights (2009) General Comment No 20: Nondiscrimination in economic, social and cultural rights (art 2, para 2, of the International Covenant on Economic, Social and Cultural Rights) E/C 12/GC/20

Committee on the Elimination of Discrimination against Women (2004) General recommendation No 25, on article 4, paragraph 1, of the Convention on the Elimination of All Forms of Discrimination against Women, on temporary special measures UN Doc A/59/38, annex I

Committee on the Elimination of Discrimination against Women (2010) General Recommendation No 28 on the core obligations of States parties under article 2 of CEDAW $\mathrm{CEDAW} / \mathrm{C} / \mathrm{GC} / 28$

Committee on the Elimination of Discrimination against Women (2014) General recommendation No 32 on the gender-related dimensions of refugee status, asylum, nationality and statelessness of women $\mathrm{CEDAW} / \mathrm{C} / \mathrm{GC} / 32$

Committee on the Elimination of Discrimination against Women and Committee on the Rights of the Child (2014) Joint general recommendation/general comment No 31 of the Committee on the Elimination of Discrimination against Women and No 18 of the Committee on the Rights of the Child on harmful practices CEDAW/C/GC/31-CRC/C/GC/18

Committee on the Elimination of Racial Discrimination (2000) General Recommendation No 25 on the gender-related dimensions of racial discrimination

Committee on the Elimination of Racial Discrimination (2010) Concluding Observations: Australia CERD/C/AUS/CO/15-17

Committee on the Rights of the Child (2003) General Comment No 3 on the rights of children with disabilities $\mathrm{CRC} / \mathrm{C} / \mathrm{GC} / 3$ 
Committee on the Rights of the Child (2006) General Comment No 9 on the rights of children with disabilities $\mathrm{CRC} / \mathrm{C} / \mathrm{GC} / 9$

Committee on the Rights of the Child (2009) General Comment No 11 on Indigenous children and their rights under the Convention $\mathrm{CRC} / \mathrm{C} / \mathrm{GC} / 11$

Committee on the Rights of the Child (2013) General Comment No 15 on the right of the child to the highest attainable standard of health (art 24) $\mathrm{CRC} / \mathrm{C} / \mathrm{GC} / 15$

Conaghan J (2009) 'Intersectionality and the feminist project in law' in E Grabham, D Cooper, J Krishnadas and D Herman (eds) Intersectionality and Beyond: Law, Power and the Politics of Location Routledge-Cavendish, Abingdon pp 21-48

Cox E (2011) 'Evidence-free policy making? The case of income management' 12 Journal of Indigenous Policy 1

Crenshaw K (1989) 'Demarginalizing the intersection of race and sex: a black feminist critique of antidiscrimination doctrine, feminist theory and antiracist politics' University of Chicago Legal Forum 139

Crooms L A (1997) 'Indivisible rights and intersectional identities or "what do women's human rights have to do with the Race Convention?" 40 Howard Law Journal 619-40

Dasgupta S and Sudarshan R (2011) Issues in Labour Market Inequality and Women's Participation in India's National Rural Employment Guarantee Programme Working Paper No 98, International Labour Organization

Equality Rights Alliance (2011) Women's Experience of Income Management in the Northern Territory Equality Rights Alliance, Canberra

Fredman S (2008a) 'Positive rights and duties: addressing intersectionality' in D Schiek and V Chege (eds) European Union Non-Discrimination Law: Comparative Perspectives on Multidimensional Equality Law Routledge-Cavendish, Abingdon pp 73-90

Fredman S (2008b) Human Rights Transformed: Positive Rights and Positive Duties Oxford University Press, Oxford

Fredman S (2011) Discrimination Law Oxford University Press, Oxford

Goldblatt B (2014) 'Testing women's right to social security in Australia: a poor score' in B Goldblatt and L Lamarche (eds) Women's Rights to Social Security and Social Protection Hart, Oxford pp 263-85

Goldblatt B and Rosa S (2014) 'Social security rights: campaigns and courts' in M Langford, B Cousins, J Dugard, and T Madlingozi (eds) Socio-Economic Rights in South Africa: Symbols and Substance Cambridge University Press, Cambridge pp 253-74

Grabham E (2009) 'Intersectionality: traumatic impressions' in E Grabham, D Cooper, J Krishnadas and D Herman (eds) Intersectionality and Beyond: Law, Power and the Politics of Location Routledge-Cavendish, Abingdon pp 183-201

Green L (2002) 'Gender hate propaganda and sexual violence in the Rwandan genocide: an argument for intersectionality in international Law' 33 Columbia Human Rights Law Review $733-76$

Holmes R, Sadana N and Rath S (2010) Gendered Risks, Poverty and Vulnerability in India: Case Study of the Indian Mahatma Gandhi National Rural Employment Guarantee Act (Madya Pradesh) Indian Institute of Dalit Studies, New Delhi 
Human Rights Committee (2009) Concluding Observations: Australia CCPR/C/AUS/CO/5

Khera R and Nayak N (2011) 'Women workers and perceptions of the NREGA' in R Khera (ed) The Battle for Employment Guarantee Oxford University Press, Oxford

Liebenberg S and Goldblatt B (2007) 'The interrelationship between equality and socioeconomic rights in South Africa's transformative constitution' 23 South African Journal on Human Rights 335

Makkonen T (2002) Multiple, Compound and Intersectional Discrimination: Bringing the Experience of the Most Marginalized to the Fore Institute for Human Rights, Abo Akademi University

Mansour J (2012) 'Consolidation of Australian anti-discrimination laws: an intersectional perspective’ 21 Griffith Law Review 533-54

Ministry of Rural Development, India (2013) Mahatma Gandhi National Rural Employment Guarantee Act 2005: Operational Guidelines (4th edn) Government of India, New Delhi

Ministry of Rural Development, India (2014) NREGA statistics [Online] Available: http://mnregaweb4.nic.in/netnrega/all_lvl_details_dashboard_new.aspx [19 June 2015]

Sheppard C (2012) 'Mapping anti-discrimination law onto inequality at work: expanding the meaning of equality in international labour law' 151 International Labour Review 1-19

Thornton M (1990) The Liberal Promise: Anti-Discrimination Legislation in Australia Oxford University Press, Melbourne

United Nations Secretary General (2009) Compilation of guidelines on the form and content of reports to be submitted by States parties to the international human rights treaties 3 June, HRI/GEN/2 Rev 6

Watson I (2012) 'The future is our past — we once were sovereign and we still are' 8 Indigenous Law Bulletin 12

Watson N (2011) 'The Northern Territory Emergency Response: has it really improved the lives of Aboriginal women and children?' 35 Australian Feminist Law Journal 147 